\section{WASHINGTON DC}

Prospects for US stem-cell research brightened considerably last week when a key Republican senator backed the idea of loosening funding restrictions on the work.

In a speech on the floor of the Senate on 29 July, majority leader Bill Frist (Republican, Tennessee) endorsed efforts to increase federal funding for research on newly derived human embryonic stem-cell lines. He said that President George Bush's policy of limiting the use of federal funds to a handful of lines derived before 9 August 2001 needed changing.

"I believe the president's policy should be modified," Frist said. "We should expand federal funding and current guidelines governing stem-cell research, carefully and thoughtfully staying within ethical bounds."

Frist's announcement makes it much more likely that the Senate will pass legislation similar to that already passed by the House of Representatives, which voted to loosen funding restrictions in May (see Nature 435, 544-545; 2005). Research advocates even say that Frist's speech might make it possible for the Senate to later override a promised presidential veto of the bill - although the return of the bill to the House is unlikely to gather similar levels of support.
And whether or not the bill passes this year, they say, Frist's speech marks a turning point in the US debate on stem-cell research, because of his highly visible role in the Republican party and the Senate. "The ramifications of this are huge," says Kevin Wilson, director of public policy at the American Society for Cell Biology.

Frist had said recently that he was opposed to modifying the president's policy, and his change of mind was a surprise to many people involved in the stem-cell debate. But Nature has learned that Frist consulted with at least two scientists just days before his speech.

On 27 July, Frist spoke to Irving Weissman, a stem-cell pioneer at Stanford University and an outspoken critic of the president's policy. Weissman told him that the stem-cell lines currently approved for research cannot be used for therapeutic trials in people because they are probably contaminated with mouse viruses. $\mathrm{He}$ also explained that US companies are likely to need licences to develop therapies using the best techniques in the field, which have been pioneered by South Korean researchers.

"I told him that prohibiting a line of research has consequences, not just from a scientific perspective, but also from both economic and health perspectives," Weissman says.

The fact that Frist's speech placed strong

\section{IMAGE UNAVAILABLE FOR COPYRIGHT REASONS}

Bill Frist heads for the Senate to announce his support for changes to rules on stem-cell research.

emphasis on the development of potential treatments is encouraging, Weissman adds. "I knew something was going to happen, but I

\title{
More falling foam puts shuttle programme in serious doubt
}

After an embarrassingly large chunk of foam fell off the external fuel tank of the space shuttle Discovery during its 26 July launch, NASA has suspended further shuttle flights until the problem is solved. But as the agency has already spent two years and well over $\$ 1$ billion trying to make the shuttle safe, critics say there will be no quick solution.

A similar piece of foam fell off Columbia's fuel tank during take-off in January 2003. The hole it punched in the shuttle's wing caused the craft to burn up on re-entry, killing all seven astronauts inside. At the insistence of the Columbia Accident Investigation Board (CAIB), NASA has poured resources into ensuring the safety of future missions, in particular to secure the insulating foam that prevents ice from building up on the fuel tank.
Although the foam that came off Discovery's tank last week didn't hit the craft, the size of the chunk, which weighed about 400 grams, shows that despite all the effort the problem is as big as ever.

Agency administrator Michael Griffin says it will be fixed "in short order", and has put together a 'tiger team' to look for answers. But many engineers question what NASA can do that it hasn't tried already. "Unless there is a significant redesign, there will always be a safety issue with this foam," says Henry McDonald, former head of the NASA Ames Research Center in California, and now at the University of Tennessee at Chattanooga.

Developing new foam could take at least a year, he says, with redesigns to the tank taking even longer. As the ageing shuttle fleet is due to be decommissioned in 2010,
McDonald argues that NASA should now cut its losses and stop shuttle flights for good.

Doug Osheroff, a physicist at Stanford University in California, and a member of the CAIB, agrees that small tweaks won't help much, but major changes could take years. "We clearly don't understand all the mechanisms for foam shedding," he says.

The best way for NASA to quickly reduce the risk to the shuttle crew is to fly with fewer people, Osheroff says. "There's no reason to go up with seven astronauts."

As Nature went to press, Discovery's crew was preparing to make emergency repairs, unrelated to the foam incident, to the craft's underside. For the latest news on the shuttle's progress, see www.nature.com/ news/specials/returntoflight. Mark Peplow 